\title{
Tanulmányok
}

\section{A DIKTATÚRA LÉTREHOZÁSA ÉS A HUMÁN TUDOMÁNYOS ELIT (1946-1948)}

\section{ESTABLISHMENT OF DICTATORSHIP AND THE HUMAN SCIENCES' ELITE 1946-1948}

\author{
N. Szabó József \\ csc, dr. habil, professor emeritus, Nyíregyházi Egyetem \\ enikoszakos@gmail.com
}

\section{ÖSSZEFOGLALÁS}

1947 tavaszától a demokráciával szakító Magyar Kommunista Párt (MKP) elhatározta, hogy az egyetemekről és a tudományos intézményekből eltávolítják az ellenforradalmi reakció képviselőit. Az 1947-es augusztusi választások után a monopolisztikus hatalomgyakorlást megvalósítani szándékozó kommunisták számára a bölcsészkarok (BTK) konzervatív professzorai is elfogadhatatlanokká váltak. 1947-ben több támadás történt a humántudományi elit ellen, de a legnagyobb kihívás az MKP 1948. június 8-án elkészített, de nyilvánosságot nem kapott felsőoktatási reformtervében éri a bölcsészeket. A tervezetben a párt az egyetemekről több tudományosan magas színvonalon álló bölcsészprofesszort el kívánt távolítani, és helyettük kommunista oktatókat szándékozott kinevezni. A néhány szakmailag kimagasló kutató mellett az 1948-ban kinevezett egyetemi tanárok között csak egyetlen professzor volt, akit nem a párt delegált. A kis számban habilitált bölcsészek többsége ugyanakkor magas tudományos színvonalat képviselt. Hasonlóan magas színvonalon álltak az 1947-1948-as tanév egyetemeinek bölcsész rektorai és a dékánok. A szakmailag kiváló tudósok politikai "kötődése" igen eltérő volt, illetve egyetlen politikai irányzathoz vagy párthoz sem tartoztak. Már a kommunisták hegemonisztikus hatalomgyakorlása idején, 1947 júniusában megtartott tagválasztáson az MTA egy levelező és hét rendes tagot választott a humán tudományok képviselői közül. Mindannyian magas tudományos színvonalat képviseltek. Mindösszesen egy akadémikusnak volt pártkötődése. A formálisan is kiépült totalitárius diktatúra alatt 1948 júliusában ülésező MTA tizenöt bölcsész akadémikust választott. Voltak közöttük olyanok, akik a kommunista tudománypolitika delegáltjai közé tartoztak, egy akadémikus viszont világszínvonalon állt. Tudományos teljesítmény nélkül azonban senki sem került az akadémia tagjai közé.

\section{ABSTRACT}

Breaking with democracy, the Hungarian Communist Party decided to remove all the representatives of the "counter-revolutionary movement" from universities and scientific institutions. Following the general elections of 1947, the more conservative professors of each Faculty of Arts 
were considered to be intolerable in the eyes of the communists, who sought to monopolize state power. In 1947 there were several attacks against the elite of human sciences, but the most provoking of them came the following year, with the planned higher education reform package, completed on $8^{\text {th }}$ June 1948 . The core of the plan was to remove some highly professional and esteemed professors from the Faculty of Arts and replace them with newly appointed professors loyal to the communist regime. For the time being the situation of the Hungarian Academy of Sciences was different. The new regime had already been institutionalized, when - in July 1948 - the Academy, in session, elected fifteen scholars into membership. Some of them were representatives of the scientific communism, but one of them was an internationally recognized scholar. At this point in time, however, no one could get an Academy membership without real scientific achievements.

Kulcsszavak: totalitárius diktatúra, akadémiai és egyetemi „reform”, akadémiai tagválasztások, professzori kinevezések, habilitációk

Keywords: totalitarianism, academic and higher education reform, election of the members of the academy, appointed professors, habilitation

\section{A DEMOKRÁCIÁVAL VALÓ SZAKÍTÁS ÉS A HUMÁN TUDOMÁNYOK}

1946 öszén a magyar politikatörténetben „fordulópontot” jelentö III. kongresszuson a kommunisták kinyilvánították: „ki a nép ellenségeivel a koalícióból” (Rákosi-Szabó, 1967, 272.). Ezzel a deklarációval a párt gyakorlatilag szakított a demokrácia eddig általa is többé-kevésbé betartott játékszabályaival. A kommunista politika radikális megváltozása ugyanakkor nem tükröződött a kongresszusnak a tudománnyal kapcsolatos felfogásában, olyannyira nem, hogy a pártértekezlet tudománypolitikai kérdésekkel gyakorlatilag nem is foglalkozott. Kivételt jelentett a Moszkvából 1945 augusztusában hazatért Lukács György felszólalása, aki heves kirohanást intézett az egyetemek és a Magyar Tudományos Akadémia ellen, amelyeket a reakció fellegvárainak tartott (Gergely-Izsák, 2000, 295.).

A neves kommunista filozófus véleménye elsősorban a bölcsészekkel szemben fogalmazódott meg. Lukács támadása az egyetemek nyitottságát illetően erôsen túlzó volt, mert Hajnal István bölcsészkari dékán a Pázmány Péter Tudományegyetem rektorához és rektori tanácsához 1945. augusztus 20 -án írt jelentésében már javasolta Lukács György kinevezését az esztétikai tanszék élére. Sokat árul el az 1945-ös bölcsészkari viszonyokról, hogy Thienemann Tass Tivadar egyetemi tanár a kari tanács 1945. szeptember 1-jei ülésén szintén indítványozta a filozófus meghívását. A kari tanács 18 igenlő, 5 nemleges és 2 érvénytelen szavazattal elfogadta a kiváló filozófus meghívását az esztétikai és kultúrfilozófiai tanszékre (Urbán, 1985, 96.).

A tudománypolitikában ,visszafogott” III. kongresszus ugyanakkor döntött a hároméves tervjavaslat kidolgozásáról. A tervjavaslatot a Politikai Bizottság 
1946. december 19-én tárgyalta, a Központi Vezetőség 1947. január 11-i ülésén pedig elfogadta. A terv legfontosabb tudománypolitikai célkitüzése az volt, hogy a tudományt az ország termelőerői szolgálatába állítsa, és szoros kapcsolatba hozza a gazdasági tervezéssel (Rákosi-Szabó, 1967, 385.). A tervezetben elsősorban a müszaki és agrártudományok terén fogalmazódtak meg tudománypolitikai preferenciák, de kiemelt célként jelent meg a társadalomtudományok támogatása is. A humán tudományok fontosságának hangsúlyozására utal, hogy az elképzelések között szerepel az egyetemektől független társadalomtudományi kutatóhálózat kiépítésének gondolata. Az MKP a felállítandó Országos Társadalomtudományi Intézettől, az Általános Neveléstudományi Intézettől, valamint a Világpolitikai és a Duna-táji Intézettől a társadalomtudományi kutatások fellendülését remélte (Rákosi-Szabó, 1967, 386.).

1947 első felében a magyar tudománypolitika központi kérdése a kutatások finanszírozása, a kutatási célkitűzések iránya, valamint a tudományos életben a II. világháború után keletkezett nehézségek felszámolása volt. A megoldandó témákat az 1946/1947-es költségvetés vitájában tárgyalták. A parlamenti vita elsősorban a természettudományokról, illetve azok támogatásáról szólt (Nemzetgyülés Naplója, 1952, 146-150., 608., 613., 637., 648.).

A tudománypolitikai polémiákban a humán elit is érintett lett, mert bölcsészellenes vélemények hangzottak el a kommunisták részéről. A tudományos élet fejlesztéséról szóló javaslatában az MKP szónoka, Rudas László a budapesti egyetemen a természettudományi kar felállítását azért szorgalmazta, mert megítélése szerint a Vallás- és Közoktatásügyi Minisztérium (VKM) a humán tanszékeket és tudományokat fejleszti a természettudományokkal szemben (Nemzetgyűlés Naplója, 1952, 663.).

A kommunista vádat a VKM miniszter elutasította. Keresztury Dezső egyetértett azzal, hogy bizonyos területeken az oktatási rend megreformálásra szorul, de cáfolta, hogy a minisztérium elhanyagolja a természettudományokat. A fejlesztés elmaradása szerinte nem szándék, hanem kényszerüség (Nemzetgyűlés Naplója, 1952, 743.).

A Szociáldemokrata Párt (SZDP) tudománypolitikája ekkor elsősorban az egyetemek szemléletét kívánta átalakítani. Szalai Sándor a hallgatói szemléletalakítás érdekében kezdeményezte a budapesti szociológiai tanszéknek a legrövidebb időn belül való kibővítését és a vidéki egyetemeken, Szegeden és Debrecenben legalább egy szociológiai előadó állás szervezését (Népszava, 1947. január 12.).

1947 tavaszától a Magyar Kommunista Párt kiemelt feladatának tartotta a tudományos kutatás tervszerü vezetését és szervezését, valamint a hároméves terv célkitúzéseivel való összhangba hozását. A bölcsészek eddig azonban az MKP elképzeléseit illetóen nem mutattak affinitást. Ennek megváltoztatására ezért a kommunisták bizonyos területeken megengedhetőnek tartották diktatórikus eszközök használatát is. A siker érdekében elhatározták, hogy az egyetemekről és a 
tudományos intézményekből eltávolítják az „ellenforradalmi” reakció képviselőit. Tudománypolitikai célként ugyanakkor „még csak” azt fogalmazták meg, hogy a marxizmus a tudományban és a felsőoktatásban foglalja el azt a helyet, amely tudományos és társadalmi jelentőségének megfelel (PTI. Arch. 274-24/2). Az MKP-hez hasonlóan az SZDP is fontosnak tartotta a marxizmus tudományos életben való térhódításának elősegítését (Népszava, 1947. június 6.).

A Magyar Kommunista Pártnak a hároméves terv kidolgozására tett különböző erőfeszítéseit a Tudományos Akadémia tagjainak többsége továbbra sem akceptálta. Az Akadémia 1947. májusi gyülésén viszont egyes bölcsészek részéről már kezdeményezés történt a kommunista elképzelések támogatására. Beke Ödön baloldali politikai múlttal rendelkező nyelvész például indítványt tett arra, hogy az MTA dolgozzon ki egy hároméves tervet. Beke akadémikus kezdeményezésének azonban még nem sok támogatója akadt a testület tagjai között, mert Németh Gyula turkológuson kívül senki más nem állt az indítvány mellé (Szabad Nép, 1947. június 10.). Az MKP vezetése a tudósok közötti rossz pozíciója megváltoztatása érdekében ezért találkozót kezdeményezett a tudományos elittel. Az összejövetelre június 11-én sor is került (PTI. Arch. 274-24/14.). A pártvezetést Rákosi Mátyás, Rajk László, Molnár Erik, Révai József, Horváth Márton és Orbán László képviselte. A kommunisták által kezdeményezett találkozón elsősorban a humán tudományok egyes képviselöi vettek részt. Ott volt Németh Gyula, a Pázmány Péter Tudományegyetem 1947/1948-as tanévre megválasztott rektora és Hajnal István bölcsészkari dékán, továbbá Zsirai Miklós, Pais Dezső és Moravcsik Gyula nyelvész akadémikusok. A baloldali, illetve kommunista bölcsészeket Mérei Ferenc, Fogarasi Béla, Rudas László, Andics Erzsébet, Szimonidesz Lajos, Waldapfel József és Imre, Komjath Aladár, Vígh Károly, Tolnai Gábor és Mátrai László képviselte. A humán elitnek a politikához nem kötődő tagjai között találjuk Gyóni Mátyást, Lakó Györgyöt, illetve Makkai Lászlót (Szabad Nép, 1947. június 12.).

Az egyetemi vezetők részéről az első két felszólaló Németh Gyula és Hajnal István volt, akik a tudósok legfőbb gondjának a türhetetlen anyagi helyzetet és a mostoha kutatási körülményeket tartották. A pártvezetés részéről a problémákra reagáló Rákosi Mátyás főtitkár akceptálta a tudósok felvetését, és megígérte, hogy javítanak anyagi helyzetükön, és vállalják a tudomány támogatását. Révai József kultúrpolitikus pedig arról beszélt, hogy a hároméves tervben nagy szerepük van a természettudományoknak, de az emberek nevelése legalább olyan fontos, mint a gazdasági színvonal emelése. A párt fó ideológusa bölcsészeket foglalkoztató tudománypolitikai kérdéseket is érintett hozzászólásában, amikor kijelentette, hogy a párt nem törekszik arra, hogy a marxisták kizárólagosságát biztosítsa az egyetemeken, ugyanakkor megjegyezte, hogy ott a helye a marxizmusnak is (Szabad Nép, 1947. június 15.).

A párt legfelső vezetôinek a tudósokkal való találkozója után a kommunista irányítású Gazdasági Főtanácsnál elérte, hogy augusztus 1-től 50\%-os tudomá- 
nyos pótlékot kapjanak az egyetemi tanárok és a tudományos intézeti vezetők, továbbá az egyetemi és föiskolai tudományos személyzetnél is biztosítsák a fizetés 40\%-át (Szabad Nép, 1947. július 15.). A pótlék bevezetésétől az MKP a tudósok megnyerését és pozíciói megerősödését remélte, ami több esetben eredményesnek is mondható. A tudósoknak a párttal szembeni eddigi tartózkodásában, illetve elutasító magatartásában a fizetésemelés bizonyos csoportoknál változást hozott. Jól érzékelteti ezt két vélemény: Zsirai Miklós budapesti bölcsészkari dékán szerint a karon hároméves terv készült, amelyet hatvanhét intézet és hetven tudós állított össze (Szabad Nép, 1947. augusztus 31.). A pozitív hozzáállást mutatja Németh Gyula rektor kinyilatkoztatása is, mely szerint a kommunisták segítségéért a tudomány örökké hálás lesz (Szabad Nép, 1947. augusztus 31.). Mindkét tudományosan kiváló nyelvészről tudni kell, hogy a háború után rövidesen „,felismerték" az MKP politikai-tudománypolitikai szerepét. Természetes, hogy a rektori és dékáni hivatalokból fakadó „kötelességük” miatt nem térhettek ki bizonyos állásfoglalások elől, de esetenként az alkalmazkodásuk a szükségest meghaladta.

Annak ellenére, hogy a humán elitek kevésbé kapcsolódnak a politikához, mint a jogászok vagy a közgazdászok, a baloldal, de különösen a kommunisták számára 1945-1946-ban fontos volt, hogy a népi demokratikus átalakulás követelményeinek megfelelően alakuljon a bölcsészkarok professzori garnitúrája. Mivel a magyar egyetemeken a professzori körben néhány szélsőjobboldali tanártól eltekintve a konzervatív gondolkodású oktatók domináltak, ezért az igazolások és bélisták idején a bölcsészek között viszonylag kevés esetben mondták ki a legsúlyosabb ítéleteket. A polgári demokrácia talaján álló politikai erők a szélsőjobb eltávolításával egyetértettek, de további tisztogatásokkal nem azonosultak. A fordulat meghirdetésétől, de különösen az 1947-es választások után a monopolisztikus hatalomgyakorlást megvalósítani szándékozó kommunisták számára a konzervatív egyetemi tanárok is elfogadhatatlanokká váltak. Az MKP úgy látta, hogy a népi demokrácia megvalósítását veszélyeztető professzorokat el kell távolítani az egyetemekről.

1947-ben több támadás érte a humántudományi elitet, de a legnagyobb kihívás az MKP 1948. június 18-án elkészített, de nyilvánosságot nem kapott felsőoktatási reformtervében érte a bölcsészeket. A probléma fontosságát jelzi, hogy a párt a pedagógusképzésre vonatkozóan „csak” a bölcsészkarok átalakítására tett javaslatot, a természettudományi oktatással nem is foglalkozott. Ezt a leszűkítést a párt azzal indokolta, hogy a bölcsészkarokon olyan tanszabadság érvényesül, amely a szakképzést teljesen dezorganizálja. A bölcsészképzésre fókuszált reformot az MKP azzal is magyarázta, hogy a tanárképzés a tudományos kutatás viszonyának a tisztázatlansága, kaotikus állapotokat teremtett, és ez mindkét feladat megoldását akadályozza. A dolgozat a bölcsészelit kérdéseivel foglalkozik, ezért nem tekinti feladatának a pedagógusképzés elemzését. Egy rövidesen megjelenő tanulmányomban a feltárom ezt a problémát is. A kommunista reform szervezeti 
javaslata az volt, hogy az egységes Bölcsészettudományi Kar helyett létesüljön Bölcsészettudományi és Természettudományi Kar. A kötött tanmenetek bevezetése a kommunisták szerint a bölcsészkaron a Tanárképző Intézetet feleslegessé teszi. Az MKP-tervezet az „ad personam” létesített „felesleges” tanszékeket meg kívánta szüntetni. Példaként említette a III. sz. Olasz Tanszéket és a II. sz. Archeológiai Tanszéket, valamint azt, hogy a külön Összehasonlító Irodalomtudományi Tanszék mellett Összehasonlító Irodalomtörténeti Tanszék is van. A tanárképzés új, szocialista szükségletének megfelelően ugyanakkor közgazdasági és társadalomtudományi tanszékek felállítását is tervezte. A hallgatók alapos és rendszeres képzése érdekében a kommunista tervezet egy relatív tanszabadság biztosítása mellett kötött tanmenetet kívánt bevezetni. A színvonalas képzés garantálásával a tervezet gondoskodni kívánt arról, hogy a hallgatók két idegen nyelvet is tanuljanak. Az MKP felfogása szerint a reform csak személyi változásokkal valósítható meg. A párt a következő bölcsészprofesszorokat kívánta eltávolítani a budapesti bölcsészkarról: Schwartz Elemért, Gerevich Tibort, Huszti Józsefet, Alszeghy Zsoltot, Lukinich Imrét és Lassovszky Károlyt. Az MKP ugyanakkor be kívánta vinni az egyetemre Molnár Eriket és Andics Erzsébetet.

A szegedi egyetemről Mester Jánost, a debreceniről pedig Mészáros Edét kívánták elmozdítani. A szegedi egyetemre a párt két kommunista oktatót javasolt professzornak: Waldapfel Imrét és Halász Elődöt. Az eltávolítandó professzorok helyére az elképzelés kivétel nélkül magasabb színvonalú tanárokat akart kinevezni (PTI. Arch. 274-21/74.).

Az elvi célkitüzéssel kapcsolatban a problémák azáltal jelentkeztek, hogy a lecserélendő professzorok valamennyien magas tudományos színvonalat képviseltek. Politikailag esetleg egy személlyel kapcsolatban „lehetett” volna kifogása a pártnak. Gerevich Tibor kiváló müvészettörténész a Gömbös-kormány idején müvészetpolitikusként valóban szerepet játszott az olasz novecentismo törekvések magyarországi megvalósításában. A többiek viszont politikailag nem „kompromittálódtak". Magas szakmai szinten állt Huszti József klasszika-filológus és Lukinich Imre történész, valamint Lassovszky Károly csillagász, továbbá Mester János és Mészáros Ede, akiknek szakmai-tudományos munkájához szintén nem fért kétség.

A bölcsészkarokra a párt által bevinni szándékozott professzorok közös jellemzője az volt, hogy valamennyien MKP-tagok voltak. Egyesek közülük bevállalták a párt célkitüzéseinek minden további nélküli megvalósítását. Volt olyan is, aki nem mondható ugyan pártkatonának, de a párt tudományos elvárásaihoz egyértelműen igazodott. Olyan is akadt közöttük, aki illegális múltja ellenére szakmaiságot is megtestesített. Egy olyan támogatottal is találkozunk, aki inkább volt professzor, mint kommunista párttag.

A június 8-án elkészült egyetemi reformelképzelések nem kerültek sem az MKP IV. kongresszusa elé, de nem tárgyalta a javaslatokat az SZDP XXXVII. 
kongresszusa sem. Az MDP I. kongresszusa sem foglalkozott a reformmal kapcsolatos elképzelésekkel (Rákosi-Szabó, 1967, 581-582., 585., 600-601.). A kongresszusok után több pártfórumon és bizottsági ülésen is értékelték és elfogadták a tervezetet (Ladányi, 1989, 34.), nyilvánosságot a kormányrendelet a Köznevelés 1948. október 15-i számában kapott $(1948,20$.). Ha összehasonlítjuk a nyilvánosságot nem kapott júniusi tervet az október 15-én megjelent kormányrendelettel, azt látjuk, hogy az egyes szakok, valamint a képzésre szánt idő részletes ismertetése mellett az anyag koncepcionálisan nem tünik kidolgozottnak. Kutatási témánk szempontjából fontos, a bölcsészelitet érintő professzori kinevezésekkel a kormányrendelet csak az általánosság szintjén foglalkozik. A publikált anyag egy része a bölcsészkarok „színvonaltalanságát”, illetve ideológiai zürzavarát tárja fel, hangsúlyozva, hogy a professzorok a népi demokráciával ellenséges tanokat hirdetnek, a marxizmus-leninizmus képviselői alig találhatók meg az egyetemeken.

\section{PROFESSZORI KINEVEZÉSEK ÉS HABILITÁCIÓK A FORDULAT UTÁN}

1946 öszén néhány orvos- és jogi kari professzori kinevezés mellett csak két bölcsész egyetemi tanári felterjesztés történt. Novemberben a Pázmány Péter Tudományegyetem régészeti tanszékére nevezték ki Nagy Lajost, a mủvészettörténetre pedig Genthon Istvánt (Magyar Közlöny, 1946, 242-243.). Megállapíthatjuk, hogy mindkét professzor kiváló tudós és oktató volt. Nagy Lajos Budapest környéki római császárkori és őskeresztény emlékek régészeti feltárása és dokumentálása, müvészettörténeti elemzése terén alkotott kiemelkedőt. Genthon István müvészettörténész kivételes műveltségü tudós pedig a magyar mủvészet nemzetközileg is elismert kutatója volt. A Bölcsészettudományi Kar új professzorai megérdemelten lettek az egyetem tanárai. A kinevezéseknek nem volt sem politikai, sem sajtóvisszhangjuk.

1946 decemberében azonban már a baloldali pártok és a kommunista irányítású Magyar Pedagógusok Szakszervezetének érdeklődésébe kerültek a professzori kinevezések. A szakszervezet Balla Antalnak a Közgazdasági Kar Gazdaságtörténeti Tanszékére való egyetemi tanári kinevezése ellen tiltakozott. Ugyanakkor viszont támogatta Berlász Jenő kinevezését (Szabad Nép, 1946. december 5.). Egyetérthetünk a szakszervezetnek azon véleményével, hogy Berlász tudományosan felkészült kutató volt, de Balla Antal akadémikus tudományos kvalitásaihoz sem férhetett volna kétség.

1947 első felében mindösszesen egy bölcsészprofesszori kinevezésre került sor. Áprilisban a Debreceni Tudományegyetem Angol Tanszékének vezetésére kapott megbízást a szakmailag kiváló Országh László (Köznevelés, 1947, 7.). Augusztusban viszont rendkívüli egyetemi tanár lett Rubinyi Mó- 
zes (Köznevelés, 1947, 16.). Ugyancsak augusztusban lett rendkívüli egyetemi tanár Barnóthy Jenő (Köznevelés, 1947, 24.).

1947 őszéig sem a politikai pártok, sem a szakszervezetek részéről nem nyilvánítottak véleményt a professzori kinevezésekkel kapcsolatosan. Kivételt jelentett a Nemzeti Parasztpárt lapja, a Szabad Szó, amely szeptember 7-i számában a szegedi egyetem bölcsész tanszékeinek munkájával foglalkozott. A parasztpárti újság nem volt megelégedve az egyetem pedagógiai és történelem tanszékeinek működésével, de szegényesnek tartotta az irodalom tanszéken folyó munkát is. Nem értett egyet azzal sem, hogy Sík Sándor távozása óta a magyar irodalom tanszék nincs betöltve, és hogy mindöszszesen két irodalmi kollégiumot hirdettek meg: Rubinyi Mózesét és Baróti Dezsőét (Szabad Szó, 1947. szeptember 7.). Újabb kinevezések csak ősszel, a választások után voltak. Szeptemberben kapott egyetemi tanári kinevezést a Pázmány Péter Tudományegyetem Ókortörténeti Tanszékére a kiváló klaszszika-filológus Marót Károly akadémikus (Köznevelés, 1947, 18.). Novemberben pedig Kondor Imre lett a Debreceni Egyetem filozófia professzora. Ugyancsak novemberben nevezték ki a szegedi egyetemre a kiváló néprajztudóst, Bálint Sándort (Köznevelés, 1947, 22.).

A professzori kinevezések terén, az egyetemek átalakításával összefüggésben a Magyar Kommunista Párt szónoka, a volt illegális kommunista orvos Weil Emil, az Orvos-Egészségügyi Dolgozók főtitkára 1947. december 10. parlamenti interpellációjában éles támadást intézett a Pázmány Péter Tudományegyetem két egyetemi tanára, Thienemann Tass Tivadar akadémikus németprofesszor és Déry József, a középkor történet egyetemi tanárai ellen (Országgyülés Naplója, 1948, 174.). Ekkor azonban már mindketten külföldön tartózkodtak, ezért gyakorlati következményei a kritikának nem lehetett. 1948 januárjában mindösszesen egy professzori kinevezés történt a bölcsészek között. A debreceni egyetem olasz tanszékére ekkor került egyetemi tanárnak Gaetano Trombatore (Köznevelés, 1948, 13.).

A bölcsészprofesszorokkal, az új kinevezésekkel kapcsolatos újabb politikai aktivitás 1948 elején kezdett kibontakozni. Rudas László az MKP egyik legharcosabb ideológus-filozófus képviselője 1948. február 24-i parlamenti felszólalásában kifejtette, hogy a magyar egyetemek sem színvonalban, sem demokratikus tekintetben nem ütik meg egy demokratikus ország követelményeit. Negatív véleménye elsősorban a szellemi tudományokra vonatkozott. Ennek megszüntetése érdekében azt követelte, hogy teremtsenek összhangot a demokrácia szükséglete és az egyetem elzárkózottsága között (Országgyülés Naplója, 1948, 642.).

Hiteltelen volt az igen szerény tudományos kvalitásokkal rendelkező Rudas számonkérése az egyetemi színvonallal kapcsolatban, ugyanígy hiteltelen volt a demokrácia szükségletének hangsúlyozása annál a képviselőnél, 
aki a parlamentben mindenkor diktatórikusan „lépett fel”, és demokráciafelfogása igencsak bonyolult volt. A kommunista professzorok elöretörésére utal, hogy áprilisban Fogarasi Béla filozófust, tudománypolitikust kinevezték a Pázmány Péter Tudományegyetemre egyetemi tanárnak. Áprilisban lett egyetemi tanár, ugyancsak a budapesti egyetem pedagógiai tanszékén Várkonyi Hildebrand Dezső (Köznevelés, 1948, 4.). A proletárdiktatúra formálisan is teljes kiépülése után a Magyar Dolgozók Pártja (MDP) létrejöttével „megteremtődtek” a feltételek a demokrácia és a „színvonal” szinkronba hozására azáltal, hogy több, az MKP-ben, illetve az illegális kommunista mozgalomban szerepet játszott pártmunkásból egyetemi tanár lett. Augusztusban kapott professzori kinevezést a szegedi tudományegyetem ókortudományi tanszékére a Magyar Kommunista Párt által támogatott Waldapfel Imre (Köznevelés, 1948, 15.). 1948 októberében lett professzor Andics Erzsébet, a budapesti bölcsészkar világtörténeti tanszékén (Köznevelés, 1948, 19.).

Az 1948-ban kinevezettek között Várkonyi Hildebrand volt az egyetlen, aki nem a párt delegáltja volt, de ugyanakkor élvezte az MKP bizalmát. Valamennyi kinevezett „megfelelt” a népi demokrácia politikai elvárásainak, tényleges tudományos teljesítményük azonban sok kívánnivalót hagyott maga után. Egyesek, mint Fogarasi Béla, már a háború előtt és után is a marxista filozófia népszerüsítése mellett önálló tudományos munkát is folytattak. Andics Erzsébet tudományos teljesítményét felülmúlta ideológiai-politikai tevékenysége. Trencsényi Waldapfel Imre politikai szerepvállalása mindig nagyobb volt kutatási kvalitásánál.

A II. világháború utáni két év habilitációit elemezve megállapíthatjuk, hogy a bölcsésztudományok területén viszonylag kevesen szereztek magántanári fokozatot. 1946 őszétől viszont nagy számban habilitáltak a magyar egyetemeken. 1946 októberében szerzett fokozatot müvészettörténetből Csapodi István, történelemből Borsodi István, egyháztörténetből Horváth Konstantin, Bakát István gazdaság- és társadalomtörténetből, Decsényi Béla pedig sajtótörténetből (Köznevelés, 1946, 20.). Novemberben habilitált irodalomból Vatai László (Köznevelés, 1946, 21.), decemberben szintén irodalomtudományból Gábor Rezső, nyelvészetből szerzett fokozatot Hasan Eren. Makkai László a történettudomány területén védett ugyancsak decemberben (Köznevelés, 1946, 23.).

1947 februárjában hadtörténelemből szerzett minősítést Szilágyi János (Köznevelés, 1947, 3.), Nagy Tibor pedig történettudományból (Köznevelés, 1947, 5.). Márciusban habilitált Telegdy Zsigmond nyelvtudományból, Dobrovics Aladár pedig történelemből (Köznevelés, 1947, 5.). 1947 májusában müvelödéstörténetből védett Juhász Vilmos (Köznevelés, 1947, 9.), júliusban pedig irodalomból Füst Milán (Köznevelés, 1947, 12.). Augusztusban két védés volt: Kósa János történettudományból, Szendrey Ákos pedig néprajzból 
(Köznevelés, 1947, 15.). Szeptemberben lett irodalomból habilitált doktor Kardos László, Kiss Tibor pszichológiából, Hegedűs Lajos pedig nyelvészetből (Köznevelés, 1947, 18.). Októberben szereztek fokozatot: Balogh István történettudományból, Kádár Zoltán klasszika-filológiából, Koczog Ákos pedig irodalomból (Köznevelés, 1947, 20.). Decemberben három védés történt: Harmatta János ókortudományból, Kovács Gyula pedagógiából, Gerevich László pedig régészetből (Köznevelés, 1947, 23-24.).

Meglepő módon az 1948-as évben a habilitációk száma erősen csökkent. Februárban Kardos Lajos pszichológiából, Péter Zoltán és Temesi Mihály filozófiából védett (Köznevelés, 1948, 3.), Jajczay János pedig egyháztörténetből (Köznevelés, 1948, 5.). 1948 áprilisában Tóth Zoltán történettudományi védésére került sor (Köznevelés, 1948, 8.). Ezután hosszú időn keresztül nem került sor habilitációkra, majd augusztusban volt még négy védés, Beke Ödön és Lutter Tibor nyelvészetből, Körmendy Dénes filozófiából és Kádár Jolán színháztörténetből szerzett fokozatot (Köznevelés, 1948, 16.).

\section{BÖLCSÉSZ VEZETŐK AZ EGYETEMEKEN}

Az 1946 őszi „,fordulat” után a bölcsészettudományok súlya a tudományos életben csökkent, ennek ellenére három egyetemi rektor bölcsészek közül került ki. Az 1946/47-es tanévben Tóth László történész lett a szegedi egyetem rektora (Köznevelés, 1946, 19.). 1946-1948 között Németh Gyula akadémikus, nyelvész a Pázmány Péter Tudományegyetem, Pukánszky Béla akadémikus, irodalomtörténész nyelvész pedig a debreceni egyetem rektora lett (Köznevelés, 1947, 16.). A bölcsészkarok vezetése úgy alakult, hogy 1946 őszétől Mészáros Ede klasszika-filológus lett a debreceni egyetem dékánja, a szegedi dékán pedig a filozófus Mester János (Köznevelés, 1946, 19.) 1947 öszétől Zsirai Miklós nyelvész akadémikus irányította a Pázmány Péter Tudományegyetem Bölcsészettudományi Karát, Pukánszky Béla a debreceni bölcsészkart, Birkás Géza pedig a szegedi BTK-t (Köznevelés, 1947, 16.). A rektorok terén az 1948-49-es tanévben annyi „változás” történt, hogy továbbra is rektor maradt Németh Gyula a budapesti, Pukánszky Béla pedig a debreceni egyetemen (Köznevelés, 1948, 16.).

A bölcsészkari rektorok kinevezésével kapcsolatosan megállapíthatjuk, hogy szakmailag valamennyien kiváló tudósok voltak, politikai kötődésüket nézve viszont igen eltérő talajon ,álltak”. Németh Gyula, a nemzetközileg is jegyzett orientalista 1947-től egyetértő ,támogatója” volt a Magyar Kommunista Párt tudománypolitikájának. Tóth László egyetemes történész is elismert kutató volt, aki azonban pártpolitikai szerepet is vállalt. 1947-ben a kisgazdapárt parlamenti képviselöje lett. Pukánszky Béla a német kultúra és a magyarországi német irodalom elismert müvelöje viszont nem kötődött egyetlen politikai irányzathoz és párthoz sem. 
A dékánok közül Mészáros Ede a klasszika-filológia területén széles körü és sikeres kutatásokat folytatott, politikai aktivitása nem volt. Mester János filozófus-pedagógus is széles körü tudományos munkásságot fejtett ki, politikával nem foglalkozott, ugyanakkor erős kötelékek füzték a katolikus egyházhoz. Zsirai Miklós kiváló finnugor nyelvész a magyar nyelvtudomány számos problémáját kutatta, és a szovjet nyelvészeti irodalom eredményeit elsők között „ismerte fel” a magyar nyelvészek között, és a Magyar Kommunista Párt tudománypolitikájának támogatójává vált. Birkás Géza a francia irodalom és kultúra kutatója is színvonalasan művelte tudományterületét, de politikai kötődése nem volt. Bárczi Géza akadémikus nyelvész, kiváló tudományos tevékenysége mellett pártpolitikával nem foglalkozott.

Látható, hogy a nyolc bölcsész vezető közül egy professzor vállalt aktív politikai szerepet a polgári erők oldalán mint országgyülési képviselö, amiről 1948 novemberében azonban lemondott. Két bölcsész vezetőnek baloldali pártkötődése volt, egy dékánnál kimutatható korábbi katolikus egyházi kapcsolata.

A bölcsészrektorok és -dékánok fele arra törekedett, hogy elsődlegesen a szakmáját művelje.

\section{BÖLCSÉSZEK A MAGYAR TUDOMÁNYOS AKADÉMIÁN}

1946-ban két olyan nagygyülés volt az Akadémián, amelyen új tagokat választottak. Az első július 24-én, a második már a fordulat után, december 19-én zajlott le. A decemberi MTA gyülésen a bölcsészek közül a testületbe nem került be egyetlen levelező és rendes tag sem, ugyanakkor a tiszteleti tagok közé választották Kodály Zoltán zenetudóst (Feketéné, 1975, 548-550.).

Az 1947. június 8-i tagválasztások alkalmából mindösszesen egyetlen bölcsész levelező tagot választottak a testület tagjának: Szemerényi Oszvald nyelvészt. Viszont heten rendes tagok lettek a humán tudományok képviselöi közül. Ekkor lett rendes tag Bárczi Géza nyelvész, Alszeghy Zsolt irodalomtörténész, Eckhardt Sándor irodalomtörténész, Kniezsa István nyelvész, Ligeti Lajos nyelvész, Rédei Tivadar irodalomtörténész és Turóczi-Trostler József irodalmár (Feketéné, 1975, 550.).

Az akadémiai tagválasztások jellemzője volt, hogy különösebb társadalmi és politikai véleménynyilvánítás nélkül zajlottak, és hogy a megválasztott új akadémikusok szakmai tudományos teljesítményük alapján lettek az MTA tagjai. Konkrét pártkötődése, illetve politikai aktivitása csak Turóczi-Trostler József irodalmárnak volt, aki azonban már az 1918-as, 1919-es forradalmak idején is szerepet vállalt a baloldalon, a Horthy-rendszer idején a Szociáldemokrata Párt munkásakadémiájának előadója volt, eközben sokoldalú tudományos munkát is folytatott, folyóiratot szerkesztett, 1945 után pedig az SZDP országgyülési képviselője lett, de szakmai tevékenységével nem szakított politizálása idején. 
Az MDP létrejötte után, a formálisan is már létező diktatúra idején 1948. július 2-án ülésezett az MTA következő tagválasztó nagygyűlése, ahol levelező tag lett Fülep Lajos müvészettörténész, Gyóni Mátyás bizantológus, Hadrovics László nyelvész, Keresztury Dezső irodalomtörténész, Lakó György nyelvész, Mátrai László filozófus, Rubinyi Mózes nyelvész, Szalai Sándor szociológus, Tolnai Gábor irodalomtörténész, Waldapfel József irodalomtörténész. Ekkor lett rendes tag Zsolnai Béla irodalomtörténész, tiszteli tag pedig Fogarasi Béla, Lukács György filozófusok, Molnár Erik filozófus-történész, valamint Schöflin Aladár irodalomtörténész (Feketéné, 1975, 550.).

Annak ellenére, hogy a totalitárius diktatúra már kiépült, az új akadémiai tagok összetételében ez még egyértelmüen nem képződött le. Voltak olyanok, akik a kommunista tudománypolitika delegáltjai voltak, de közöttük is differenciálni kell. Például Lukács György világszínvonalat képviselt, de viszonylagos színvonalat jelentett Fogarasi Béla és Molnár Erik is. Az 1950-es évek törvénysértésének áldozatává vált, majd a 60 -as évektől tudományosan kibontakozó Szalai Sándornak a tudománypolitikai és tudományszervező tevékenysége ekkor még meghatározóbb volt, mint a tudományos teljesítménye. Az irodalmárok és a nyelvészek eddigi tudományos teljesítményeik alapján lettek akadémikusok, illetve a későbbiek során bizonyított szakmaiságuk alapján megérdemelten kerültek a tagok közé. A polgári irracionalizmust bíráló Mátrai László is a tudományt képviselte az akadémikusok között. Az 1948-ban beválasztott MTA tagok közül hárman az 1948-es „reform” után elsődlegesen politikai okok miatt már nem lehettek a testület tagjai.

A „reform” után az Akadémián 1949. október 31-én megválasztott akadémikusok között több szakmai-tudományos kiválóság is volt, de a taktikát kiszolgáló tudománypolitika koncepciója az 1949-es, majd az azt követő tagválasztásoknál már egyértelmúen kimutatható. Ezekben az években a Révai-féle kultúrpolitika következményeként több olyan „tudóst” is bejuttattak az MTA-ra, akik nem tudományos kvalitásuk alapján, hanem politikai érdemeik révén lettek az Akadémia tagjai. Az átszervezés következménye volt az is, hogy az MTA tagjainak nagy részét, százhatvan főt tanácskozó taggá minősítettek, ami által gyakorlatilag megfosztották őket akadémiai tagságuktól. A jogfosztottak 50\%-a a humán tudományokhoz tartozott.

\section{IRODALOM}

Beck M. - Peschka V. (főszerk.) (1989): Akadémiai Kislexikon. II. kötet. Budapest: Akadémiai Kiadó

Fekete G.-né (összeáll.) (1975): A Magyar Tudományos Akadémia Tagjai, 1825-1975. Budapest: MTA Könyvtára

Gergely J. - Izsák L. (2000): A huszadik század története. Budapest: Pannonica Kiadó 
Kónya S. - Pach Zs. P. (főszerk.) (1975): A Magyar Tudományos Akadémia másfél évszázada 18251975. Budapest: Akadémiai Kiadó

Ladányi A. (1989): Mennyiségi fejlödés és strukturális változások: a felsőoktatás útja a felszabadulás után. Budapest: Tankönyvkiadó-Oktatáskutató Intézet

Rákosi S. - Szabó B. (szerk.): (1967): A Magyar Kommunista Párt és a Szociáldemokrata Párt határozatai 1944-1948. Budapest: Kossuth Könyvkiadó

Urbán K. (1985): Lukács György és a magyar munkásmozgalom. Budapest: Kossuth Könyvkiadó

\section{Források}

Köznevelés (1946-1948)

Magyar Közlöny 1946

Népszava 1947

Nemzetgyülés Naplója (1952) VI. kötet, Budapest. Hiteles kiadás

Országgyülés Naplója (1948) III. kötet, Budapest. Hiteles kiadás

Párttörténeti Intézet Archívuma (PTI. Arch.)

Szabad Nép (1946-1948) 